\section{Improvement of the methodology of the tetrazolium test using different pretreatments in seeds of the genus Epidendrum (Orchidaceae)}

\author{
Seir Antonio Salazar Mercado ${ }^{1 *}$ (D) Jesús David Quintero Caleño (i), \\ Laura Yolima Moreno Rozo ${ }^{1}$ iD
}

\begin{abstract}
The aim of the present study was to determine the most suitable pretreatment to enhance the tetrazolium test in seeds of the Epidendrum genus. Initially, mature capsules were harvested at El Escorial village, in the municipality of Pamplona, Colombia. Subsequently, the seeds were subjected to five pretreatments: deionized water, $0.5 \% \mathrm{NaClO}, 1.0 \% \mathrm{NaClO}, 10.0 \%$ sucrose and a control group. Using the syringe method with cloth filter, the seeds were rinsed with distilled water and subjected to two concentrations of tetrazolium solution $(0.25 \%, 1.0 \%)$ and three exposure times ( 6 h, $24 \mathrm{~h}$ and $48 \mathrm{~h}$ ). Finally, the tetrazolium viability test results were correlated with the in vitro germination test. It was found that the use of deionized water improves the efficiency of the tetrazolium test in seeds of Epidendrum fimbriatum and E. microtum; as in seeds of E. elongatum when using $1.0 \%$ tetrazolium for $24 \mathrm{~h}$. Similarly, a high correlation was found between viability and germination, using deionized water and $10.0 \%$ sucrose, with homogeneous results with each other.
\end{abstract}

Index terms: orchid, sodium hypochlorite, sucrose, seed viability.

\section{Aprimoramento da metodologia doteste detetrazólio utilizando diferentes pré-tratamentos em sementes do gênero Epidendrum (Orchidaceae)}

RESUMO: O objetivo do presente estudo foi determinar o pré-tratamento mais adequado para aprimorar a metodologia do teste de tetrazólio em sementes do gênero Epidendrum. Inicialmente, cápsulas maduras foram coletadas na vila de El Escorial, no município de Pamplona, Colômbia. Em seguida, as sementes foram submetidas a cinco pré-tratamentos: água deionizada, $\mathrm{NaClO}$ a $0,5 \%, \mathrm{NaClO}$ a $1,0 \%$, sacarose a 10,0\% e um controle. Utilizando o método de seringa com filtro de pano, as sementes foram lavadas com água destilada e submetidas a duas concentrações de solução de tetrazólio $(0,25 \%$ e $1,0 \%)$ e três tempos de exposição (6 h, $24 \mathrm{~h}$ e $48 \mathrm{~h}$ ). Finalmente, os resultados do teste de viabilidade do tetrazólio foram comparados ao teste de germinação in vitro. Verificou-se que o uso de água deionizada melhora a eficiência do teste de tetrazólio em sementes de Epidendrum fimbriatum e de E. microtum, assim como em sementes de E. elongatum ao usar $1,0 \%$ de tetrazólio por $24 \mathrm{~h}$. Da mesma maneira, foi encontrada alta correlação entre viabilidade e germinação, utilizando água deionizada e 10,0\% de sacarose, com resultados homogêneos.

Termos para indexação: orquidácea, hipoclorito de sódio, sacarose, viabilidade de sementes.
Journal of Seed Science, v.42, e202042013, 2020

http://dx.doi.org/10.1590/2317$1545 v 42231028$

\section{*Corresponding author} E-mail: salazar663@hotmail.com

Received: $11 / 13 / 2019$. Accepted: $2 / 17 / 2020$.

${ }^{1}$ Department of Biology, Universidad Francisco de Paula Santander, San José de Cúcuta, Norte de Santander, Postal Code 540003, Colombia.

${ }^{2}$ Department of Agricultural Sciences, Universidad Francisco de Paula Santander, San José de Cúcuta, Norte de Santander, Postal Code 540003, Colombia. 


\section{INTRODUCTION}

Orchidaceae is the largest family of flowering plants (Arditti and Ghani, 2000). It makes up one of the most diverse taxa among the phanerogams, with 30,000 recognized species, distributed in 899 genus (Ekmekçigil et al., 2019). They are present on all continents, except Antarctica (Hosomi et al., 2017). They are among the most threatened plants in the world. Colombia is considered one of the richest countries in the diversity of orchids; it is estimated that it has 4,270 species classified in 274 genera (Betancur et al., 2015).

Having about 1,500 species (Cardoso-Gustavson et al., 2018) distributed in Latin America, the neotropical genus Epidendrum stands out, as it is one of the most expressive ecologically and horticulturally (Cavalcante et al., 2018). With great diversity, it has flowers characterized by a lip with frills or fringes, being widely cultivated as an ornamental plant (Sangma et al., 2018). In Colombia there are 527 species belonging to this genus (Betancur et al., 2015).

Epidendrum is often considered to secrete a rewarding nectar (Pansarin and Pansarin, 2014). However, recent studies concluded that many of these species produce a secretion similar to nectar, as a pollinator's deterrent, which is considered by many authors as a disguise (Cardoso-Gustavson et al., 2018). Such strategy indicates the deceptive presence of food (Cozzolino and Widmer, 2005), leading to short visits by pollinators, who abandon the inflorescence after visiting a single flower, resulting in decrease of pollination and consequent reduced fruiting (Cardoso-Gustavson et al., 2018). In addition, Epidendrum producers encounter difficulties in the crop development, such as high costs, very slow sexual and vegetative propagation rate for large-scale production (Cavalcante et al., 2018). It is necessary to highlight that most studies in the genus focus on ecology and the symbiosis with endophytic fungi (Gamboa-Gaitán and Otero-Ospina, 2016). For this reason, it is necessary to establish methods that provide information on the seed viability and physiological potential, to ensure their rapid germination and uniformity in establishing in vitro plants, with reduced waste of culture media. With the definition of these methods, the conservation of genetic variability and the preservation of germplasm and clonal propagation material will be improved in germoplasm banks. Improved methods for determining seed viability might also improve propagation of these species, since seeds are their main organ of propagation, which might directly affect the crop productivity (Doria, 2010).

Currently, there are several assays to evaluate the physiological potential of seeds, which require short periods of time and are related to the integrity of cell membranes and respiratory activity. Germination and tetrazolium tests are among the main methods to evaluate the seed physiological potential (Salazar-Mercado and Vega-Contreras, 2017). The correct application of these methods is very important to generate satisfactory results (Hosomi et al., 2017). Therefore, it is necessary to identify and control aspects such as pretreatments of the seeds and tetrazolium concentrations in order to improve the methodology for performing the tetrazolium test. The 2,3,5-triphenyl tetrazolium chloride assay is qualitative for tissues and large organs when observed under a microscope. Although it seems to be destructive, the test is often used for embryos and embryonic axes, for a rapid assessment of viability (Salazar and Gélvez, 2015).

The use of pretreatments such as scarification, soaking in water and cutting, improves the diffusion of the tetrazolium solution into seed tissues, being successfully used in several species. Hosomi et al. (2011) compared in vitro germination rates of seeds of several species from the Cattleya genus with the results of viability obtained by the tetrazolium test on seeds subjected to different pretreatments. They observed that the pretreatments implementation influences the effectiveness of the tetrazolium test in seeds of this important genus from the orchid family. Consequently, the aim of the present study is to evaluate the effect of four pretreatments used in the tetrazolium test in seeds of Epidendrum microtum, E. elongatum and E. fimbriatum.

\section{MATERIAL AND METHODS}

Plant material: the experiment was carried out in the Biology Laboratory of the Universidad Francisco de Paula Santander. Mature and naturally pollinated capsules were used (Figure 1), harvested at El Escorial village, in Pamplona 
municipality, Colombia: Epidendrum microtum Lindl (N 07³4'41" W 072 $64^{\prime} 155^{\prime \prime}$, altitude: 2,870 masl), Epidendrum elongatum Jacq. ( $\mathrm{N} 07^{\circ} 34^{\prime} 78^{\prime \prime} \mathrm{W} 072^{\circ} 64^{\prime} 083^{\prime \prime}$, altitude: 2,754 masl) and Epidendrum fimbriatum Lindl ( $\mathrm{N} 07^{\circ} 34^{\prime} 476^{\prime \prime}$ W $072^{\circ} 64^{\prime} 08^{\prime \prime}$, altitude: 2,765 masl); harvested after the dehiscence (48 h later, approximately). The seeds were rinsed with distilled water for the pretreatment application to assure the same conditions for all seeds (Table 1).

Pretreatment's application and tetrazolium test: a small portion of seeds was introduced into a sterile $5 \mathrm{~mL}$ syringe with a cloth filter, applying each of the pretreatments (chlorine $0.5 \%$, chlorine $1.0 \%$, deionized water, sucrose $10.0 \%$ and a control without any substance) for a period of ten minutes each. Subsequently, three rinses were made with deionized water and the tetrazolium test was performed. Subsequently, the tetrazolium (2,3,5-triphenyl tetrazolium chloride) solutions were prepared to $0.25 \%$ and $1.0 \%$. Immediately, the seeds were immersed in the tetrazolium solution in total darkness for 6, 24 and $48 \mathrm{~h}$. At the end of the set time, the seeds were rinsed three times with distilled water and examined in the stereoscope microscope (Leica EZ4). The seed viability evaluation was performed considering the red staining pattern due to the reduction of the tetrazolium solution in the living respiring cells of the seed tissues (Salazar-Mercado and Vega-Contreras, 2017; Salazar and Delgado, 2018). Seeds were considered as viable when more than half of the seed tissue were stained and non-viable when no red staining was developed on the seeds (Figure 2). Viability was presented as percentage and evaluated for each of the replications of every treatment applied.

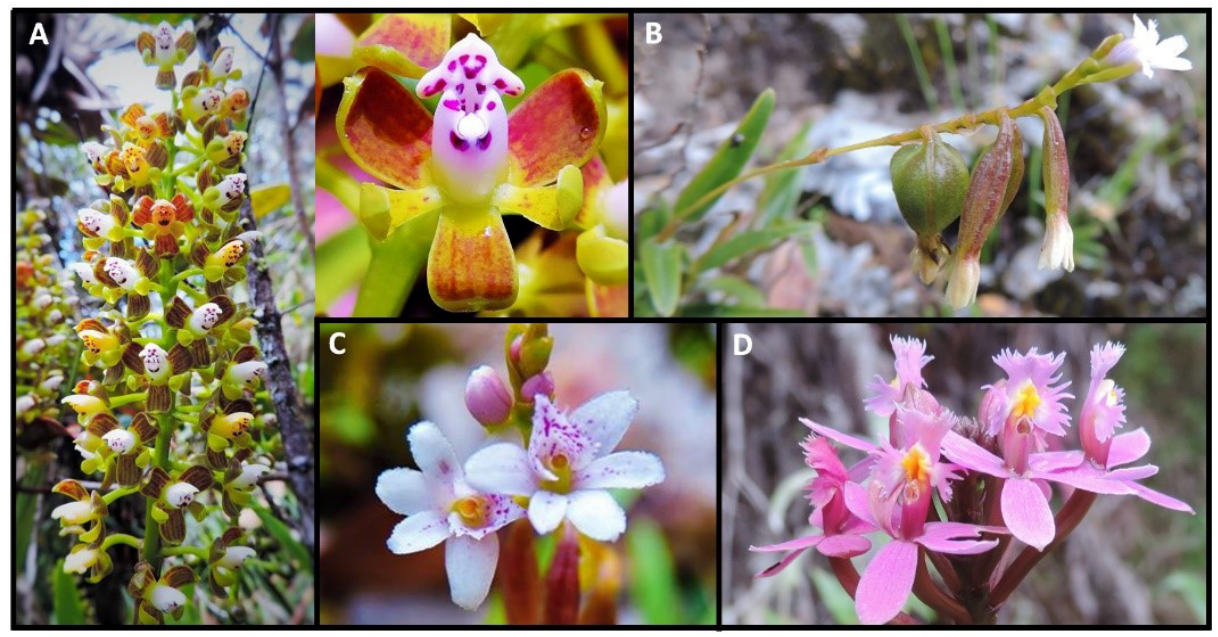

Figure 1. Flowers and capsules of orchid species of Epidendrum genus. (A) Epidendrum microtum flowers; (B) Capsule of Epidendrum fimbriatum; (C) Epidendrum fimbriatum flower; (D) Epidendrum elongatum flower.

Table 1. Epidendrum elongatum seed viability, as determined by the tetrazolium test at different solution concentrations and exposure periods.

Seed viability (\%): different tetrazolium concentrations and exposure periods

\begin{tabular}{cccccrr}
\hline Pretreatments & $0.25 \%-6 \mathrm{~h}$ & $0.25 \%-24 \mathrm{~h}$ & $0.25 \%-48 \mathrm{~h}$ & $1.0 \%-6 \mathrm{~h}$ & $1.0 \%-24 \mathrm{~h}$ & \multicolumn{1}{c}{$1.0 \%-48 \mathrm{~h}$} \\
\hline Control & $17.0 \mathrm{ab}$ & $16 \mathrm{a}$ & $14.6 \mathrm{a}$ & $4.0 \mathrm{a}$ & $9.3 \mathrm{a}$ & $14.6 \mathrm{a}$ \\
Chlorine 0.5\% & $58.6 \mathrm{~b}$ & $56 \mathrm{~b}$ & $44.0 \mathrm{~b}$ & $53.3 \mathrm{bc}$ & $53.3 \mathrm{~b}$ & $2.6 \mathrm{a}$ \\
Chlorine 1\% & $1.3 \mathrm{a}$ & $1.3 \mathrm{a}$ & $0.0 \mathrm{c}$ & $25.3 \mathrm{ab}$ & $37.3 \mathrm{~b}$ & $37.3 \mathrm{~b}$ \\
Deionized water & $5.3 \mathrm{a}$ & $100.0 \mathrm{c}$ & $96.0 \mathrm{~d}$ & $16.0 \mathrm{a}$ & $86.6 \mathrm{c}$ & $58.6 \mathrm{c}$ \\
Sucrose 10\% & $14.6 \mathrm{ab}$ & $86.6 \mathrm{c}$ & $97.3 \mathrm{~d}$ & $85.3 \mathrm{c}$ & $70.6 \mathrm{c}$ & $73.3 \mathrm{c}$ \\
\hline
\end{tabular}

Means within each column followed by the same letter do not differ by the Tukey test $(p \leq 0.05)$. 


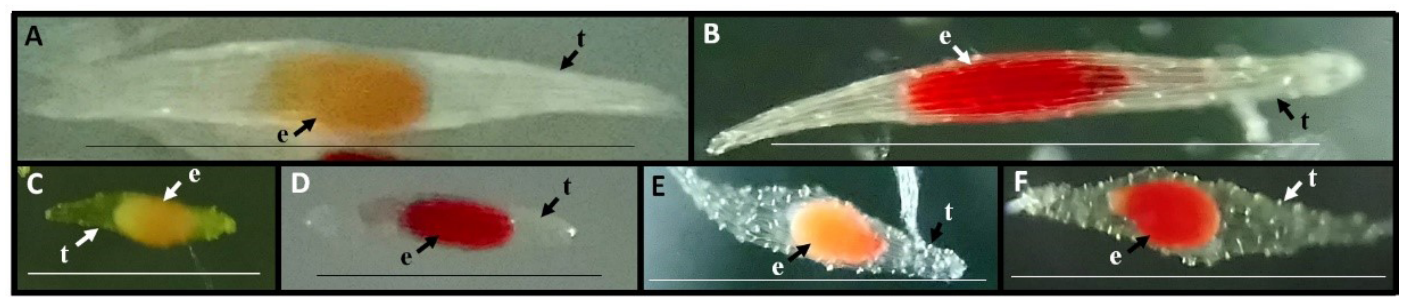

Figure 2. Viability test using tetrazolium. (A) Epidendrum microtum non-viable seed; (B) E. microtum viable seed; (C) Epidendrum elongatum non-viable seed; (D) E. elongatum viable seed; (E) Epidendrum fimbriatum non-viable seed; (F) E. fimbriatum viable seed; (t): seed coat; (e): embryo.

In vitro germination test: with very few exceptions, in vitro germination of orchid seeds became increasingly popular for viability evaluation. The disinfection and sowing of the seeds were carried out according to the methodology described by Salazar-Mercado and Vega-Contreras (2017): initially, the seeds were immersed for one minute in $70 \%$ ethanol, then immersed in a solution with $0.75 \%$ sodium hypochlorite plus $0.1 \%$ Tween-20 for five minutes; subsequently, three rinses were performed with deionized water. After removing the filter from the syringe, a hundred seeds per plate were planted, distributing them evenly on the circumference of the plate with the help of a culture handle (sterilized), in five Petri dishes with $25 \mathrm{~mL}$ of MS basal medium composed of $100 \%$ macro and micronutrients (Murashige and Skoog, 1962), supplemented with $3 \mathrm{~g} . \mathrm{L}^{-1}$ sucrose, $8 \mathrm{~g} . \mathrm{L}^{-1}$ of agar and $1 \mathrm{~g} . \mathrm{L}^{-1}$ of activated carbon. Next, the plates were sterilized at 15 pounds of pressure (Psi) at $121{ }^{\circ} \mathrm{C}$ for 25 minutes. The media were incubated under controlled conditions $\left(26 \pm 2{ }^{\circ} \mathrm{C}\right.$ with a photoperiod of $16 / 8 \mathrm{~h}$ light/darkness) with a light intensity of $25 \mu \mathrm{mol} . \mathrm{m}^{-1}$ per second, provided by fluorescent light and $60 \%$ relative humidity. The germination percentage was obtained by observing a hundred seeds per treatment with the help of a stereoscope microscope (Leica EZ4). After twelve days, the seeds that had expanded embryos and testa rupture were considered as germinated (SalazarMercado and Vega-Contreras, 2017).

Statistical analysis: for each treatment, ten replications with a hundred seeds each were used, with thirty treatments for each studied species. The data were randomly distributed and organized by means of an analysis of variance to determine the treatments' effect on the amount of viable seeds observed. Germination (in vitro) and viability (tetrazolium test) were expressed in percentage. The data were analyzed using the ANOVA analysis of variance. The mean values were compared using Tukey's test to determine the means with significant differences $(p \leq 0.05)$.

\section{RESULTS AND DISCUSSION}

Epidendrum elongatum viability: in the results presented in Table 1, it can be observed that the treatment with $0.25 \%$ tetrazolium for $6 \mathrm{~h}$ resulted in a minimum viability of $1.3 \%$ when using the pretreatment of chlorine $1 \%$, without significant differences with the values obtained by the deionized water pretreatment $(5.3 \%)$, similar to the results presented in seeds of Paphiopedilum SCBG Red Jewel seeds, where the use of $1 \%$ chlorine dramatically decreased tetrazolium staining, as reported by Fu et al. (2016). However, when using pretreatment with chlorine at $0.5 \%$, the highest viability $(58.6 \%)$ was obtained in this treatment $(0.25 \%$ for $6 \mathrm{~h})$. Next, it is observed that the use of $0.25 \%$ tetrazolium during $24 \mathrm{~h}$ resulted in a greater viability with the pretreatment of deionized water (100.0\%); this can be explained by the fact that hydration of the seed tissues improves the absorption of tetrazolium and provides the activation of the enzymatic metabolism in the living cells (Carvalho et al., 2014). Similarly, it can be noticed that the treatment with $0.25 \%$ tetrazolium for $48 \mathrm{~h}$ resulted in $0.0 \%$ viability when using $1 \%$ chlorine as pretreatment, and the use of sucrose presented $97.3 \%$ viability, similar results to those obtained by Hosomi et al. $(2011 ; 2017)$ in seeds of Cattleya species. This is because sucrose solution avoids possible imbibitional injuries, maintaining the balance between the seeds and their environment. With the $1.0 \%$ tetrazolium concentration for $6 \mathrm{~h}$, the control pretreatment exhibited the 
lowest viability (4.0\%), contrasting with that obtained by Salazar and Gélvez (2015), where seeds without pretreatment of Epidendrum sp. and Epidendrum elongatum presented $85.4 \%$ and $89.6 \%$ viability respectively (using tetrazolium at $1 \%$ ). However, pretreatment with sucrose produced the highest viability (85.3\%), since the immersion of the seeds in sucrose activates the embryo metabolism, mainly related to the action of the dehydrogenase enzymes (Hosomi et al., 2011), which produces more reliable results. Likewise, the control pretreatment resulted in the lowest viability (9.3\%), and the pretreatment with deionized water the highest (86.6\%), when using $1 \%$ tetrazolium during $24 \mathrm{~h}$.

Epidendrum fimbriatum viability: according to the obtained results in the tetrazolium test, a marked tendency in the viability increase was observed with the use of sucrose, presenting five maximum viability values (Table 2): $46.6 \%$, $98.6 \%, 97.3 \%, 80.0 \%$ and $94.6 \%$ (0.25\%-6 h, 0.25\%-24 h, 0.25\%-48 h, 1.0\%-6 h and 1\%-24 h, respectively). That is, the pretreatment with sucrose increased the viability in all the treatments except with the $1.0 \%$ treatment for $48 \mathrm{~h}$. These results ratify what was presented by Suzuki et al. (2018), where previous use of sucrose increased viability (tetrazolium $1 \%$ ) in Catasetum atratum cryopreserved seeds. However, it was demonstrated that the use of sucrose did not increase viability in seeds of Epidendrum secundum (69.15\%), Epidendrum nocturnum (31.86\%) and Epidendrum desciflorum $(42.85 \%)$, when compared with in vitro germination. Similarly, the use of chlorine at $0.5 \%$ and $1.0 \%$ did not provide significant differences between them. In addition, they showed a very marked tendency to decrease viability, with the

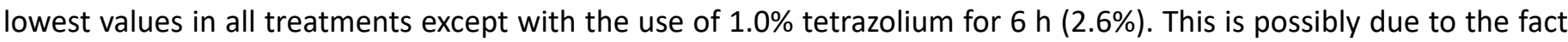
that chlorine readily penetrates the lipid cuticle and the lignified outer seed coat (Jevšnik and Luthar, 2015), which can cause damage to the embryo, since it is a strongly oxidizing compound (Jiang et al., 2017).

Epidendrum microtum viability: according to the results shown in Table 3, it was observed that the use of sucrose produced the highest viability values in comparison with other treatments, except for the results with the use of deionized water and $1.0 \%$ chlorine in the tetrazolium treatments at $0.25 \%$ for $48 \mathrm{~h}$ and with the treatment of $1.0 \%$ for $6 \mathrm{~h}$, respectively, which were $98.6 \%$ for each one. However, these results did not differ significantly from each other as compared to the use of sucrose ( $96.0 \%$ and $93.3 \%$, respectively). Similar data were presented by Custódio et al. (2016), where preconditioning with $10.0 \%$ sucrose for five minutes significantly increased the staining in Dactylorhiza fuchsii seeds ( $85.0 \%$ viabiity). On the other hand, the use of $1.0 \%$ chlorine caused the lowest viability in the treatments with $0.25 \%$ for $6 \mathrm{~h}, 1.0 \%$ for $24 \mathrm{~h}$ and $1.0 \%$ for $48 \mathrm{~h}$ (34.6\%, $76.0 \%$ and $36.0 \%$, respectively), corroborating with the results presented by Custódio et al. (2016), who worked with seeds of Vanda curvifolia, where the increase in $\mathrm{NaOCl}$ concentration had a detrimental effect on viability. Other authors reported mixed results after scarification of orchid seeds with $\mathrm{NaOCl}$, although this may be due to the use of high concentrations (1.0\% and 5.0\%) of $\mathrm{NaOCl}$ (Dowling and Jusaitis, 2012), which can interfere with the tetrazolium dehydrogenation (Lallana and García, 2013). In general, the sucrose pretreatment used showed that it works well for these species, representing a useful and basic protocol for a wide range of species (Hosomi et al., 2011).

Table 2. Epidendrum fimbriatum seed viability, as determined by the tetrazolium test at different solution concentrations and exposure periods.

\begin{tabular}{ccccccc}
\hline & \multicolumn{5}{c}{ Seed viability (\%): different tetrazolium concentrations and exposure periods } \\
\hline Pretreatments & $0.25 \%-6 \mathrm{~h}$ & $0.25 \%-24 \mathrm{~h}$ & $0.25 \%-48 \mathrm{~h}$ & $1.0 \%-6 \mathrm{~h}$ & $1.0 \%-24 \mathrm{~h}$ & $1.0 \%-48 \mathrm{~h}$ \\
\hline Control & $2.6 \mathrm{a}$ & $4.0 \mathrm{a}$ & $9.3 \mathrm{a}$ & $2.6 \mathrm{a}$ & $9.3 \mathrm{a}$ & $10.6 \mathrm{a}$ \\
Chlorine 0.5\% & $2.6 \mathrm{a}$ & $2.6 \mathrm{a}$ & $2.6 \mathrm{a}$ & $10.6 \mathrm{a}$ & $1.3 \mathrm{~b}$ & $2.6 \mathrm{~b}$ \\
Chlorine 1\% & $12.0 \mathrm{a}$ & $1.3 \mathrm{a}$ & $2.6 \mathrm{a}$ & $10.6 \mathrm{a}$ & $1.3 \mathrm{~b}$ & $1.3 \mathrm{~b}$ \\
Deionized water & $46.6 \mathrm{~b}$ & $94.6 \mathrm{~b}$ & $96.0 \mathrm{~b}$ & $80.0 \mathrm{~b}$ & $98.6 \mathrm{c}$ & $13.3 \mathrm{ac}$ \\
Sucrose 10\% & $46.6 \mathrm{~b}$ & $98.6 \mathrm{~b}$ & $97.3 \mathrm{~b}$ & $80.0 \mathrm{~b}$ & $94.6 \mathrm{c}$ & $17.3 \mathrm{c}$ \\
\hline
\end{tabular}

Means within each column followed by the same letter do not differ by the Tukey test $(p \leq 0.05)$. 
Table 3. Epidendrum microtum seed viability, as determined by the tetrazolium test at different solution concentrations and exposure periods.

Seed viability (\%): different tetrazolium concentrations and exposure periods

\begin{tabular}{ccccccc}
\hline Pretreatments & $0.25 \%-6 \mathrm{~h}$ & $0.25 \%-24 \mathrm{~h}$ & $0.25 \%-48 \mathrm{~h}$ & $1.0 \%-6 \mathrm{~h}$ & $1.0 \%-24 \mathrm{~h}$ & $1.0 \%-48 \mathrm{~h}$ \\
\hline Control & $81.3 \mathrm{a}$ & $84 \mathrm{ab}$ & $81.3 \mathrm{a}$ & $88.0 \mathrm{a}$ & $86.6 \mathrm{ab}$ & $89.3 \mathrm{ac}$ \\
Chlorine 0.5\% & $92.0 \mathrm{ac}$ & $96.0 \mathrm{~b}$ & $72.0 \mathrm{a}$ & $90.6 \mathrm{a}$ & $94.6 \mathrm{ab}$ & $86.6 \mathrm{a}$ \\
Chlorine 1\% & $34.6 \mathrm{~b}$ & $82.6 \mathrm{a}$ & $81.3 \mathrm{a}$ & $98.6 \mathrm{a}$ & $76.0 \mathrm{a}$ & $36.0 \mathrm{~b}$ \\
Deionized water & $96.0 \mathrm{c}$ & $78.6 \mathrm{a}$ & $98.6 \mathrm{a}$ & $90.6 \mathrm{a}$ & $96.0 \mathrm{ab}$ & $96.0 \mathrm{~cd}$ \\
Sucrose 10\% & $96.0 \mathrm{c}$ & $96.0 \mathrm{~b}$ & $96.0 \mathrm{a}$ & $93.3 \mathrm{a}$ & $98.6 \mathrm{~b}$ & $97.3 \mathrm{~d}$ \\
\hline
\end{tabular}

Means within each column followed by the same letter do not differ by the Tukey test $(p \leq 0.05)$.

Germination in vitro: seed expansion was observed twelve days after sowing, three days before as reported by Salazar-Mercado and Vega-Contreras (2017). According to Sulong et al. (2016), the absorption of water and nutrients leads to a protocorm formation and later to rhizoids formation. In the case of Epidendrum elongatum Jacq., $90.0 \%$ of germination (in vitro) was obtained, data that correlates with the viability obtained with the use of $1.0 \%$ tetrazolium for $24 \mathrm{~h}$, using distilled water as pretreatment (86.6\%). Likewise, it correlates to a lesser degree with the $85.5 \%$ obtained in the treatment of $1.0 \%$ for $6 \mathrm{~h}$, using sucrose (pretreatment) and moving further away from the viability obtained with the other treatments. This would imply in cost reduction of the procedure, since it is not necessary to use chlorine or sucrose as pretreatment in these species, resulting in a greater number of samples that can be evaluated (Carvalho et al., 2017). In the case of Epidendrum fimbriatum Lindl, 93.0\% germination was obtained, statistically homogeneous data with $94.6 \%$ of viability presented in the treatments with tetrazolium at $0.25 \%$ for 24 $\mathrm{h}$ and deionized water (pretreatment) and $1.0 \%$ tetrazolium for $24 \mathrm{~h}$ and sucrose (pretreatment), placing the use of sucrose and deionized water as the best options among the pretreatments, independently of the concentration and time of exposure to tetrazolium. In the same way, 97.0\% germination was obtained in seeds of Epidendrum microtum, homogeneous data within several results obtained with the tetrazolium test, such as when sucrose (pretreatment) was used in treatments with $0.25 \%$ tetrazolium for 6,24 and $48 \mathrm{~h}$ and $1 \%$ tetrazolium for 24 and $48 \mathrm{~h}$. Likewise, the use of deionized water as pretreatment in the tetrazolium test caused great homogeneity with the germination test (Table 3). Therefore, it can be inferred that regardless the concentration and time of exposure to the tetrazolium solution, the use of sucrose and distilled water increases the efficiency of the test in Epidendrum microtum seeds, reiterating that the use of deionized water represents a lower cost compared to the use of chlorine and sucrose. Regarding the use of chlorine as pretreatment, according to Salazar-Mercado et al. (2019) and Mercado and Bayona (2020), this chemical compound causes cell abnormalities at low concentrations, which could affect the viability and germination of orchid seeds. Therefore, the use of sodium hypochlorite for pretreatment of orchid seeds is not recommended. Additionally, it was observed that the exposure to tetrazolium solutions (for the two concentrations) at $24 \mathrm{~h}$ is homogeneous with the results obtained after $48 \mathrm{~h}$; so it is recommended not to extend the test to $48 \mathrm{~h}$ in any of the three species tested on this research.

\section{CONCLUSIONS}

It was concluded that pretreatment with deionized water improves the efficiency of the tetrazolium test in Epidendrum elongatum Jacq. seeds when $1.0 \%$ tetrazolium concentration is used during $24 \mathrm{~h}$. Likewise, the use of distilled water is seen as a viable and economic alternative to increase the efficiency of the tetrazolium test in Epidendrum fimbriatum Lindl seeds, showing a better correlation with the actual germination (in vitro). Likewise, although the use of distilled water and sucrose as pretreatment in the tetrazolium test in Epidendrum microtum seeds produced homogenous 
results among them, the use of distilled water is recommended, due to the economic factor. Finally, it is important to mention that the use of chlorine (1.0 and $0.5 \%)$ in most cases decreases the effectiveness of the tetrazolium test.

\section{ACKNOWLEDGEMENTS}

To Universidad Francisco de Paula Santander (Cúcuta, Colombia) for their valuable collaboration and project financing (FINU-UFPS: 037-2019).

\section{REFERENCES}

ARDITTI, J.; GHANI, A. Numerical and physical properties of orchid seeds and their biological implications. New Physiologist, v.145, p. 367-421, 2000. http://www.jstor.org/stable/2588806.

BETANCUR, J.; SARMIENTO, H.; TORO-GONZÁLEZ, L.; VALENCIA, J. Plan para el estudio y la conservación de las orquídeas en Colombia. Bogotá D.C.: Ministerio de Ambiente y Desarrollo Sostenible; Universidad Nacional de Colombia, 2015. 336p. https:// www.researchgate.net/publication/276268416_Plan_para_el_estudio_y_la_conservacion_de_las_orquideas_en_Colombia

CARDOSO-GUSTAVSON, P.; SAKA, M.N.; PESSOA, E.M.; PALMA-SILVA, C.; PINHEIRO, F. Unidirectional transitions in nectar gain and loss suggest food deception is a stable evolutionary strategy in Epidendrum (Orchidaceae): insights from anatomical and molecular evidence. BMC Plant Biology, v.18, n.179, 2018. doi:10.1186/s12870-018-1398-y

CARVALHO, I.L.; MENEGHELLO, G.E.; TUNES, L.M.; JÁCOME, C.C.; SOARES, V.N. Methodological adjustments to the tetrazolium test in rice seeds. Journal of Seed Science, v.39, n.1, p.41-49, 2017. http://www.scielo.br/scielo.php?script=sci_ arttext\&pid=S2317-15372017000100041

CARVALHO, T.C.; GRZYBOWSKI, C.R.S.; OHLSON, O.C.; PANOBIANCO, M. Adaptation of the tetrazolium test method for estimating the viability of sorghum seeds. Journal of Seed Science, v.36, n.2, p.246-252, 2014. http://www.scielo.br/scielo.php?script=sci arttext\&pid=S2317-15372014000200014

CAVALCANTE, V.R.; BORIN, L.; PEDROSO-DE-MORAES, C. Germinação e crescimento in vitro de Epidendrum secundum Jacq. (Orchidaceae) em diferentes meios de cultivo e períodos de exposição a agentes desinfestantes seminais. Iheringia Serie Botanica, v.75, n.2, p.201-207, 2018. 328048105_Germinacao_e_crescimento_in_vitro_de_Epidendrum_secundum_Jacq_Orchidaceae_ em_diferentes_meios_de_cultivo_e_periodos_de_exposicao_a_agentes_desinfestantes_seminais

COZZOLINO, S.; WIDMER, A. Orchid diversity: an evolutionary consequence of deception? Trends in Ecology and Evolution, v.20, n.9, p.487-494, 2005. https://www.sciencedirect.com/science/article/pii/S0169534705001928?via\%3Dihub

CUSTÓDIO, C.C.; MARKS, T.R.; PRITCHARD, H.W.; HOSOMI, S.T.; MACHADO-NETO, N.B. Improved tetrazolium viability testing in orchid seeds with a thick carapace (Dactylorhiza fuchsii) or dark seed coat (Vanda curvifolia). Seed Science and Technology, v.44, n.1, p.1-12, 2016. https://www.researchgate.net/publication/301239013_Improved_tetrazolium_viability_testing_in_Orchid_ seeds_with_a_thick_carapace_Dactylorhiza_fuchsii_Or_dark_seed_coat_Vanda_curvifolia

DORIA, J. Generalidades sobre las semillas: su producción, conservación y almacenamiento. Cultivos Tropicales, v.31, n.1, p.74-85, 2010. http://scielo.sld.cu/scielo.php?script=sci_arttext\&pid=S0258-59362010000100011

DOWLING, N.; JUSAITIS, M. Asymbiotic in vitro germination and seed quality assessment of Australian terrestrial orchids. Australian Journal of Botany, v.60, n.7, 592-601, 2012. https://www.publish.csiro.au/bt/BT12133

EKMEKÇIGIL, M.; BAYRAKTAR, M.; AKKUŞ, Ö.; GÜREL, A. High-frequency protocorm-like bodies and shoot regeneration through a combination of thin cell layer and RITA $^{\circledR}$ temporary immersion bioreactor in Cattleya forbesii Lindl. Plant Cell, Tissue and Organ Culture, v.136, p.451-464, 2019. https://link.springer.com/article/10.1007\%2Fs11240-018-1526-2

FU, Y.Y.; JIANG, N.; WU, K.L.; ZHANG, J.X.; SILVA, J.A.T.; DUAN, J.; LIU, H.T.; ZENG, S.J. Stimulatory effects of sodium hypochlorite and ultrasonic treatments on tetrazolium staining and seed germination in vitro of Paphiopedilum SCBG Red Jewel. Seed Science and Technology, v.44, n.1, p.77-90, 2016. https://www.researchgate.net/publication/300046293_Stimulatory_effects_of_sodium_hypochlorite_and_ ultrasonic_treatments_on_tetrazolium_staining_and_seed_germination_in_vitro_of_Paphiopedilum_SCBG_Red_Jewel

GAMBOA-GAITÁN, M.A.; OTERO-OSPINA, J.T. Colombian vanilla and its microbiota. III. Diversity and structure of the endophytic community. Acta Botanica Hungarica, v.58, n.3-4, p.241-256, 2016. https://pdfs.semanticscholar.org/ b959/504db543281ba5151c7459778a39578cab91.pdf?_ga=2.119553931.2054264221.1582035103-302932642.1582035103 
HOSOMI, S.T.; SANTOS, R.B.; CUSTÓDIO, C.C.; SEATON, P.T.; MARKS, T.R.; MACHADO-NETO, N.B. Pre-conditioning Cattleya seeds to improve the efficacy of the tetrazolium test for viability. Seed Science and Technology, v.39, n.1, p.178-189, 2011. https://www.researchgate.net/ publication/233616817_Preconditioning_Cattleya_seeds_to_improve_the_efficacy_of_the_tetrazolium_test_for_viability

HOSOMI, S.T.; SOUZA, T.B.; CUSTÓDIO, C.C.; MACHADO-NETO, N.B. Refining the tetrazolium test for evaluation of Cattleya labiata and C. tigrina seeds viability. Australian Journal of Crop Science, v.11, n.10, p.1320-1326, 2017. http://www.cropj.com/ hosomi_11_10_2017_1320_1326.pdf

JEVŠNIK, T.; LUTHAR, Z. Successful disinfection protocol for orchid seeds and influence of gelling agent on germination and growth. Acta Agriculturae Slovenica, v.105, n.1, p.95-102, 2015. http://ojs.aas.bf.uni-lj.si/index.php/AAS/article/view/29

JIANG, H.; CHEN, M.; LEE, Y. In vitro germination and low-temperature seed storage of Cypripedium lentiginosum P.J.Cribb \& S.C. Chen, a rare and endangered lady's slipper orchid. Scientia Horticulturae, v.225, p.471-479, 2017. https://doi.org/10.1016/j. scienta.2017.07.040

LALLANA, V.H.; GARCÍA, L.F. Efecto de pretratamientos en la prueba de viabilidad de semillas de Trichocentrum jonesianum (Orchidaceae). Investigación Agraria, v.15, n.2, p.129-132, 2013. http://scielo.iics.una.py/pdf/ia/v15n2/v15n2a08.pdf

MERCADO, S.A.S.; BAYONA, H.A.M. Evaluation of the cytotoxic potential of sodium hypochlorite using meristematic root cells of Lens culinaris Med. Science of The Total Environment, v.701, 2020. https://doi.org/10.1016/j.scitotenv.2019.134992

MURASHIGE, T.; SKOOG, F. A revised medium for rapid growth and bioassays with tobacco tissue culture. Physiologia Plantarum, v.15, p.437-497, 1962. https://doi.org/10.1111/j.1399-3054.1962.tb08052.x

PANSARIN, E.R.; PANSARIN, L.M. Reproductive biology of Epidendrum tridactylum (Orchidaceae: Epidendroideae): a rewardproducing species and its deceptive flowers. Plant Systematics and Evolution, v.300, n.2, p.321-328, 2014. http://dx.doi.org/10.1007/ s00606-013-0884-9 > DOI: 10.1007/s00606-013-0884-9

SALAZAR, S.A.; DELGADO, E.A.B. Viabilidad de semillas de Glycine max (L.) utilizando la prueba de tetrazolio. Revista de Investigación Agraria y Ambiental, v.9, n.2, p.89-98, 2018. http://hemeroteca.unad.edu.co/index.php/riaa/article/view/2270

SALAZAR, S.A.; GÉLVEZ, J.D. Determining the viability of orchid seeds using the tetrazolio and carmín índigo tests. Revista de Ciencias, v.19 n.2, p.59-69, 2015. http://www.scielo.org.co/pdf/rcien/v19n2/v19n2a04.pdf

SALAZAR-MERCADO, S.A.; TORRES-LEÓN, C.A.; ROJAS-SUÁREZ, J.P. Cytotoxic evaluation of sodium hypochlorite, using Pisum sativum L. as effective bioindicator. Ecotoxicology Environmental Safety, v.173, p.71-76, 2019. https://doi.org/10.1016/j.ecoenv.2019.02.027

SALAZAR-MERCADO, S.A.; VEGA-CONTRERAS, N.A. Asymbiotic seed germination and in vitro propagation of Cattleya trianae Linden \& Reichb.f. (Orchidaceae). Acta Agronómica, v.66, n.4, p.544-548, 2017. http://www.scielo.org.co/scielo.php?script=sci_ arttext\&pid=S0120-28122017000400544\&lng=en\&nrm=iso\&tlng=en

SANGMA, R.H.C.; PRADHAN, G.; SINGH, R.K. Seasonal incidence of aphid, Macrosiphum luteum (Hemiptera: Aphididae) on Epidendrum radicans in Sikkim Himalayas. Journal of Entomology and Zoology Studies, v.6, n.1, p.698-701, 2018. http://www. entomoljournal.com/archives/?year=2018\&vol=6\&issue=1\&Articleld=3018

SULONG, N.A.; KHALIL, N.I.M.; DAHARI, M.I.; ZAKARIA, A.A. Effect of different sound genres on in vitro seed germination of Grammatophyllum hybrid and Grammatophyllum stapeliiflorum orchids. The Open Conference Proceedings Journal, v.7, p.94103, 2016. https://www.researchgate.net/publication/302902599_Effect_of_Different_Sound_Genres_on_In_Vitro_Seed_ Germination_of_Grammatophyllum_Hybrid_and_Grammatophyllum_Stapeliiflorum_Orchids

SUZUKI, A.B.P.; VIDAL, T.C.M.; ALVES, G.A.C.; BERTONCELLI-JUNIOR, D.; BIZ, G.; SORACE, M.; FARIA, R.T. Cryopreservation of Brazilian orchid (Catasetum atratum Lindl.) seed at risk of extinction. Australian Journal of Crop Science, v.12, n.7, p.1051-1057, 2018. https://www.cropj.com/suzuki_12_7_2018_1051_1057.pdf 